\title{
Conceptual Framework of Supply Chain Management - Information System for Curriculum Management Based on Thailand Qualifications Framework for Higher Education
}

\author{
Artaphon Chansamut $^{1}$, Asst. Prof. Dr. Pallop Piriyasurawong ${ }^{2}$ \\ ${ }^{1 *}$ Ph.D. candidate, Information and Communications Technology for Education \\ Faculty of Technical Education, King Mongkut's University of Technology North \\ Bangkok \\ 1518 Pracharat 1 Road, Wong Sawang Sub-District, Bang Sue District, Bangkok 10800 \\ ${ }^{2}$ Assistant Professor, Division of Information and Communications Technology \\ for Education Faculty of Technical Education, King Mongkut Institute of Technology \\ North Bangkok \\ 1518 Pracharat 1 Road, Wong Sawang Sub-District, Bang Sue District, Bangkok 10800
}

\begin{abstract}
The objectives of this research are (1) to synthesize a conceptual framework of supply chain managementinformation system (SCM-IS) for curriculum management based on Thailand Qualifications Framework for Higher Education; and (2) to evaluate the conceptual framework of supply chain management- information system (SCM-IS) for curriculum management based on Thailand Qualifications Framework for Higher Education. The research sample totalling 10 experts consisted of five experts on supply chain management, two experts on curriculum, and three experts on information technology. The employed research instrument is a questionnaire. Statistics employed for data analysis are mean and standard deviation.
\end{abstract}

The research methodology consisted of six phases: (1) the studies and syntheses of related documents, research studies, and articles; (2) the drafting of preliminary conceptual framework; (3) the identification of experts; (4) the development of an evaluation form to assess appropriateness of the conceptual framework; (5) the data collection and analysis; and (6) the final improvement of the conceptual framework based on suggestions of the experts.

Research findings show that the synthesized conceptual framework of supply chain managementinformation system (SCM-IS) for curriculum management based on Thailand Qualifications Framework for Higher Education comprises four main components, namely, Suppliers, University (Manufacturer), Education Customers, and Consumer. Evaluation results by the experts show the evaluation rating mean of 4.07 with standard deviation of 1.10 indicating that the conceptual framework is considered to be at the good level. Furthermore, evaluation results of appropriateness for sub-components are as follows:

1. The appropriateness rating mean for sub-components of the Supplier component is 4.15, which can be interpreted to be at the good level.

2. The appropriateness rating mean for sub-components of the University component is 4.20, which can be interpreted to be at the good level. This is because the University component contains the sub-components at the decision making level of the educational supply chain. 
3. The appropriateness rating mean for sub-components of the Education Customers component is 4.20, which can be interpreted to be at the good level. This is because the Education Customers component contains the sub-components of direct service receivers.

4. The appropriateness rating mean for sub-components of the Consumer component is 4.10, which can be interpreted to be at the good level. This is because the Consumer component contains the sub-component of customers as the end-of-supply chain process that affect the quality of graduates to be delivered to the society.

The overall evaluation result for the synthesized conceptual framework of supply chain managementinformation system (SCM-IS) for curriculum management based on Thailand Qualifications Framework for Higher Education shows the overall rating mean of 4.14 and standard deviation of 1.00, which means that the synthesized conceptual framework is appropriate at the high level and can be appropriately applied in actual work settings.

\section{KEYWORDS}

Supply Chain Management, Information System, Curriculum Management, Thailand Qualifications Framework for Higher Education

\section{INTRODUCTION}

In this globalization age, the Thai government has realized the importance of adjusting the country to increase its capability to compete with other countries in every aspect. Especially in educational development that leads to development of quality of the people, the government has formulated the following policy: "To develop quality of people, as the people are human resource of the country and the key component in all aspects of development, to reform the whole system of education, to expand education and modify educational structure, to decentralize educational administration to the provinces so that educational management becomes more thorough and responsive to the local needs." [1]. This policy also includes the establishment of private and public higher education institutions to meet the needs for national development and development of individuals who want to further their studies. Furthermore, there are factors affecting educational development of the country as follows:

1. Internal factors. In B.E. 2542, the Thai government promulgated the Educational Reform Act that brings about the changes in educational structure, and the promotion of educational institutions toward academic and vocational excellences. In order for educational institutions to be more inspirational and interesting for prospective students, higher education institutions need to adjust themselves to cope with economic, political and social changes that occur in the country. Meanwhile, the country needs human resource with high level of knowledge and ability, especially the people who are knowledgeable and skillful in various vocations, to work in private and public organizations. Higher education institutions need to produce graduates to meet the needs of the country and to prepare the people to be ready for joining the ASEAN Economic Community in B.E. 2558.

2. External factors. Various countries have increased their competitive ability by developing their human resources to equip them with knowledge and skills in order to create quality products in agriculture and industry. One of their strategies is the application of the supply chain management system in human resource development in order to increase competitive ability. As Thailand is a part of world community, it needs to urgently develop its educational system in order to provide more opportunities for people to be educated and increase their potential. As such, the government has formulated an important policy that "The creation of a stable knowledge-based economy and environmental factors must support Thailand to be a center of goods and service production in the region based on creative thinking, creation of innovations, 
and extension of the body of knowledge in order to support the adjustment of the structure of production and service sector in every stage of supply chain. This is to enable the creative economy to be a new mobilizing power that leads toward the balanced and sustainable economy in the long run, together with the creation of the assurance system and the supply chain system, the management of economic risks, and the creation of the free and just atmosphere to facilitate the production, commerce and investment inclusive of the development of new entrepreneurs, the creation of infrastructure and internal logistics networks that connect with other countries in the region." Based on this policy, the $11^{\text {th }}$ National Plan for Social and Economic Development was formulated. [2].

The researcher has realized the importance of curriculum development in order to cope with economic, social and political changes. In the business and industrial sector the changes have included the movement toward more and more application of the concept of supply chain management information system. This is because the business and industrial sector needs to be highly competitive due to increasingly high competitions from both within and outside the country. In order to be highly competitive, organizations in the sector need to have personnel with knowledge, ability and skills who can work efficiently to increase output and products. The organizations, therefore, need to have sufficient information and resources to increase their values and respond to the demand of their clients. Thus, the supply chain management process is a key process to support the organization's whole activities system from upstream to downstream. It enables the organization to promptly check the information system to ensure that the organization operates smoothly and effectively based on the determined strategies. Based on this realization, the researcher has decided to synthesize a conceptual framework of supply chain managementinformation system for curriculum management based on Thailand Qualifications Framework for Higher Education for application to increase values of enterprises and educational institutions and increase satisfaction of consumers.

\section{RESEARCH OBJECTIVES}

1. To synthesize a conceptual framework of SCM-IS for curriculum management based on Thailand Qualifications Framework for Higher Education.

2. To evaluate the conceptual framework of SCM-IS for curriculum management based on Thailand Qualifications Framework for Higher Education.

\section{RESEARCH HYPOTHESIS}

The conceptual framework of SCM-IS for curriculum management based on Thailand Qualifications Framework for Higher Education is evaluated to be appropriate at the high level.

\section{RESEARCH INSTRUMENTS}

1. The synthesized conceptual framework of SCM-IS for curriculum management based on Thailand Qualifications Framework for Higher Education.

2. A questionnaire to assess the expert's opinions toward the synthesized conceptual framework of SCM-IS system for curriculum management based on Thailand Qualifications framework for Higher Education.

\section{RESEARCH SCOPE}

1. Population and Sample. The research sample of evaluators of the synthesized conceptual framework consisted of five experts on supply chain management, two experts on curriculum management, and three experts on information technology system. 
2. Independent Variable. The independent variable is the synthesized conceptual framework of SCM-IS for curriculum management based on Thailand Qualifications Framework for Higher Education.

3. Dependent Variable. The dependent variable is the evaluation result of the synthesized conceptual framework of SCM-IS for curriculum management based on Thailand Qualifications Framework for Higher Education.

\section{RESEARCH METHODOLOGY}

The research methodology comprised six following steps:

Step 1: Studies and syntheses of theories, documents and research literature both within and outside the country concerning SCM-IS, curriculum management, and Thailand Qualifications Framework on Higher Education.

Step 2: Drafting of a conceptual framework of supply chain management- information system for curriculum management based on Thailand Qualifications Framework for Higher Education as drawn from results of studies of documents and related research literature in Step 1.

Step 3: Identification of experts for evaluation of the synthesized conceptual framework. The researcher determined that they must be experts on supply chain management, curriculum, and information technology. All of them must have educational qualification at the doctoral degree level, and must have more than two years of work experience.

Step 4: Development of a questionnaire for the experts to assess the appropriateness of the components of the synthesized conceptual framework as follows:

1. The appropriateness of the main components

2. The appropriateness of sub-components of the suppliers component

3. The appropriateness of sub-components of the university (manufacture) component

4. The appropriateness of sub-components of the education customers component

5. The appropriateness of sub-components of the consumers component

The developed questionnaire was a 5-scale rating questionnaire, with interpreted meanings as follows:

$\begin{array}{llll}\text { The rating of } & 5 & \text { means } & \text { most appropriate. } \\ \text { The rating of } & 4 & \text { means } & \text { highly appropriate. } \\ \text { The rating of } & 3 & \text { means } & \text { moderately appropriate. } \\ \text { The rating of } & 2 & \text { means } & \text { lowly appropriate. } \\ \text { The rating of } & 1 & \text { means } & \text { least appropriate. }\end{array}$

Step 5: Data collection and analysis. The developed questionnaire was sent to the experts in order to ask their opinions on appropriateness of the developed conceptual framework. Responses from the experts were analyzed to find the mean and standard deviation of each component. Criteria for interpretation of the means are as follows: [3]

The rating means ranging from $4.51-5.00$ means appropriate at the highest level. The rating means ranging from $3.51-4.50$ means appropriate at the high level.

The rating means ranging from $2.51-3.50$ means appropriate at the moderate level. The rating means ranging from $1.51-2.50$ means appropriate at the low level. 
International Journal of Managing Value and Supply Chains (IJMVSC) Vol. 5, No. 4, December 2014

The rating means ranging from $0.00-1.50$ means appropriate at the lowest level.

Step 6: Final improvement of the developed conceptual framework based on suggestions from the experts.

\section{RESEARCH FINDINGS}

\section{Research Findings on the Developed Conceptual Framework}

Research findings on the developed conceptual framework of SCM-IS for curriculum management based on Thailand Qualifications Framework for Higher Education are presented in Figure 1 for the whole conceptual framework and in Tables $1-5$ that shows detailed information on the components of the conceptual framework, as shown below:

Suppliers

University (Manufacturer)

Education Customers Consumers

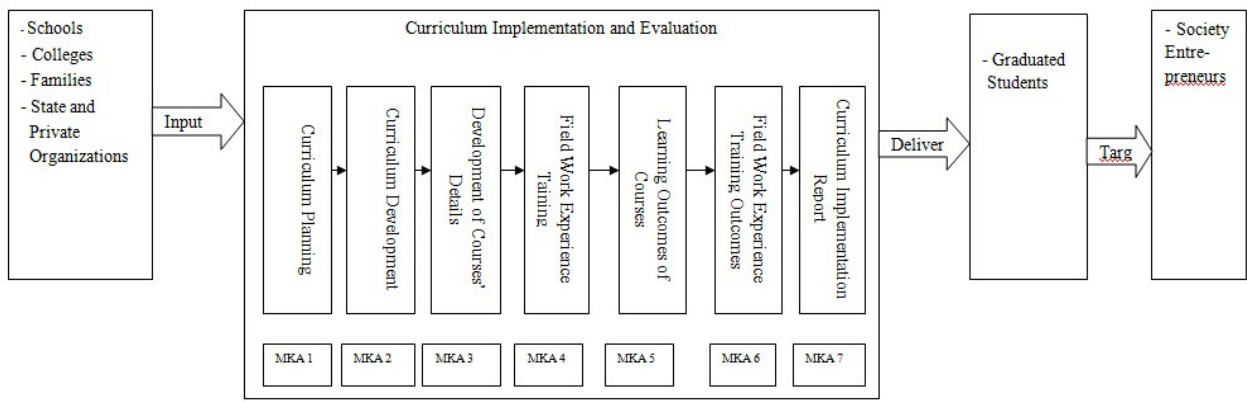

Figure 1: Conceptual Framework of SCM-IS for Curriculum Management Based on Thailand Qualifications Framework for Higher Education

Table 1: The Component of Suppliers, with Its Stakeholders, Activities, and Needs for Information

\begin{tabular}{l|l|l}
\hline \multicolumn{1}{c|}{ Suppliers } & \multicolumn{1}{|c}{ Activities } & \multicolumn{1}{|c}{ Needs for Information } \\
\hline Stakeholders: & - Supplying graduated high & - To reduce time in the \\
1. School & school students & admission process, with \\
2. College & - Supplying self-supported & quick responses and \\
3. Family & students & reduction of time wastage. \\
4. State and Private & - Providing funding support & - To be easy to monitor and \\
Organizations & follow up. \\
& for study & \\
& - Providing educational & \\
& scholarships & \\
\hline
\end{tabular}


Table 2: The Component of University (Manufacturer) with Its Steps of Curriculum Implementation and Evaluation, Activities, and Needs for Information

\begin{tabular}{|c|c|c|}
\hline $\begin{array}{c}\text { University } \\
\text { (Manufacturer) }\end{array}$ & Activities & Needs for Information \\
\hline $\begin{array}{l}\text { Steps of Curriculum } \\
\text { Implementation and } \\
\text { Evaluation: } \\
\text { 1. Curriculum Planning } \\
\text { (MKA 1) }\end{array}$ & $\begin{array}{l}\text { - Staff recruitment and } \\
\text { student admission }\end{array}$ & $\begin{array}{l}\text { - To facilitate and speed up } \\
\text { the recruitment and admission } \\
\text { processes. } \\
\text { - To be filed and stored } \\
\text { systematically to prevent the } \\
\text { loss of information. }\end{array}$ \\
\hline $\begin{array}{l}\text { 2. Curriculum } \\
\text { Development (MKA 2) }\end{array}$ & $\begin{array}{l}\text { - Planning for and } \\
\text { development of the } \\
\text { curriculum including its } \\
\text { objectives, scope, structure, } \\
\text { contents, course description, } \\
\text { evaluation system, and } \\
\text { required resources. } \\
\text { - Development of curriculum } \\
\text { documents, instructional } \\
\text { media and certificates. }\end{array}$ & $\begin{array}{l}\text { - To facilitate the filing and } \\
\text { storage of large amount of } \\
\text { information for accessibility. } \\
\text { - To facilitate the } \\
\text { coordination between various } \\
\text { sections. } \\
\text { - To be easily accessible. } \\
\text { - To facilitate the evaluation } \\
\text { of instructor's instruction and } \\
\text { evaluation of resource usage. }\end{array}$ \\
\hline $\begin{array}{l}\text { 3. Development of } \\
\text { Courses Details (MKA 3) }\end{array}$ & $\begin{array}{l}\text { - Determination of course } \\
\text { objectives, scope, contents, } \\
\text { learning activities, printed } \\
\text { and electronic learning } \\
\text { media, and evaluation } \\
\text { system. } \\
\text { - Provision of buildings and } \\
\text { facilities including the } \\
\text { classrooms, laboratories, } \\
\text { library, and learning } \\
\text { resources. } \\
\text { - Provision of course } \\
\text { materials including texts, } \\
\text { study guides, printed and } \\
\text { electronic learning media, } \\
\text { and equipment. }\end{array}$ & $\begin{array}{l}\text { - To facilitate speedy and } \\
\text { accurate data processing and } \\
\text { analysis. } \\
\text { - To eliminate overlapping } \\
\text { and duplicating work } \\
\text { performances. }\end{array}$ \\
\hline
\end{tabular}


International Journal of Managing Value and Supply Chains (IJMVSC) Vol. 5, No. 4, December 2014

Table 2: The Component of University (Manufacturer) with Its Steps of Curriculum Implementation and Evaluation, Activities, and Needs for Information (Cont.)

\begin{tabular}{|c|c|c|}
\hline University (Manufacturer) & Activities & Needs for Information \\
\hline $\begin{array}{l}\text { Steps of Curriculum } \\
\text { Implementation and } \\
\text { Evaluation: }\end{array}$ & & \\
\hline $\begin{array}{l}\text { 4. Fieldwork Experience } \\
\text { Training (MKA 4) }\end{array}$ & $\begin{array}{l}\text { - Determination of } \\
\text { objectives, scope, activities, } \\
\text { and evaluation of fieldwork } \\
\text { experience. } \\
\text { - Provision of fieldwork } \\
\text { experience training } \\
\text { including training places, } \\
\text { supervising staff and } \\
\text { mentors, training handbook } \\
\text { and materials, and seminars } \\
\text { on training experience. }\end{array}$ & $\begin{array}{l}\text { - To facilitate speedy and } \\
\text { accurate data processing } \\
\text { and analysis. } \\
\text { - To eliminate overlapping } \\
\text { and duplicating work } \\
\text { performances. }\end{array}$ \\
\hline $\begin{array}{l}\text { 5. Learning Outcomes of } \\
\text { Courses (MKA 5) }\end{array}$ & $\begin{array}{l}\text { - Reporting of learning } \\
\text { outcomes in each domain } \\
\text { including the knowledge, } \\
\text { intellectual skill, attitude, } \\
\text { morality, interpersonal } \\
\text { relationship, numerical } \\
\text { analysis, information } \\
\text { technology usage, etc. } \\
\text { - Evaluation of learning } \\
\text { outcomes of students based } \\
\text { on their grade point average. } \\
\text { - Reporting of instructional } \\
\text { evaluation of instructors. }\end{array}$ & $\begin{array}{l}\text { - Valid and accurate } \\
\text { evaluation information. }\end{array}$ \\
\hline $\begin{array}{l}\text { 6. Fieldwork Experience } \\
\text { Training Outcomes } \\
\text { (MKA 6) }\end{array}$ & $\begin{array}{l}\text { - Reporting of fieldwork } \\
\text { experience training } \\
\text { outcomes in terms of } \\
\text { performance based on the } \\
\text { rating scores of } 1-5 \\
\text { according to evaluation } \\
\text { criteria. }\end{array}$ & $\begin{array}{l}\text { - Valid and accurate } \\
\text { evaluation information. }\end{array}$ \\
\hline $\begin{array}{l}\text { 7. Curriculum } \\
\text { Implementation Report } \\
\text { (MKA 7) }\end{array}$ & $\begin{array}{l}\text { Reporting of curriculum } \\
\text { implementation outcomes in } \\
\text { terms of the following: } \\
\text { - Number of students who } \\
\text { graduate before the } \\
\text { completion of curriculum } \\
\text { implementation. }\end{array}$ & $\begin{array}{l}\text { - Correct and complete } \\
\text { evaluation reports. } \\
\text { - Speedy and up-to-date } \\
\text { evaluation reports. }\end{array}$ \\
\hline
\end{tabular}


International Journal of Managing Value and Supply Chains (IJMVSC) Vol. 5, No. 4, December 2014

Table 2: The Component of University (Manufacturer) with Its Steps of Curriculum Implementation and Evaluation, Activities, and Needs for Information (Cont.)

\begin{tabular}{l|l|l}
\hline University (Manufacturer) & \multicolumn{1}{|c}{ Activities } & Needs for Information \\
\hline $\begin{array}{l}\text { Steps of Curriculum } \\
\text { Implementation and }\end{array}$ & $\begin{array}{l}\text { - Number of students who } \\
\text { graduate according to the } \\
\text { Evaluation: }\end{array}$ & \\
7. Curriculum & $\begin{array}{l}\text { - Number of students who } \\
\text { graduate in each major } \\
\text { Implementation Report }\end{array}$ & \\
(MKA 7) & $\begin{array}{l}\text { field of study. } \\
\text { - Occupations taken up by } \\
\text { graduate students from the } \\
\text { university. } \\
\end{array}$ & \\
& - Level of satisfaction of & \\
final year students with & & \\
& the curriculum. & \\
\hline
\end{tabular}

Table 3: The Component of Education Customers, with Desirable Qualities, and Needs for Information

\begin{tabular}{|c|c|c|}
\hline Education Customers & Desirable Qualities & Needs for Information \\
\hline Graduated students & $\begin{array}{l}\text { 1. Having good knowledge in } \\
\text { their field of study. } \\
2 \text {. Having work performance } \\
\text { skills. } \\
\text { 3. Having all desirable } \\
\text { characteristics. }\end{array}$ & $\begin{array}{l}\text { - Information on the number } \\
\text { of graduated students. } \\
\text { - Information that is easy to } \\
\text { gather, to process and to } \\
\text { retrieve. }\end{array}$ \\
\hline
\end{tabular}

Table 4: The Component of Consumers, with Activities and Needs for Information

\begin{tabular}{l|l|l}
\hline \multicolumn{1}{c|}{ Consumers } & \multicolumn{1}{c}{ Desirable Qualities } & \multicolumn{1}{c}{ Needs for Information } \\
\hline $\begin{array}{l}\text { 1. Entrepreneurs who employ } \\
\text { the graduated students } \\
\text { 2. The society in general }\end{array}$ & $\begin{array}{l}\text { Receiving and/or employing } \\
\text { graduated students with } \\
\text { desirable characteristics } \\
\text { including good virtues and } \\
\text { morality, good knowledge and } \\
\text { intellectual skills, good human } \\
\text { relationship skills, good } \\
\text { responsibility, good numerical } \\
\text { analysis skill, good } \\
\text { communication skill, and good } \\
\text { information technology usage } \\
\text { skills, etc. }\end{array}$ & $\begin{array}{l}\text { Qmployer's satisfaction with } \\
\text { the employed graduated } \\
\text { student on various aspects of } \\
\text { desirable characteristics. }\end{array}$ \\
\hline
\end{tabular}


Abbreviations used in Figure 1, and Tables $1-4$ :

MKA stands for Mo. Ko. Ao. (in Thai language) which means "Qualification Standards for Higher Education". There are seven qualification standards for higher education: MKA1 - MKA 7

Targ stands for "Target" which mean the delivery target, or end-of-process target. In the conceptual framework, it includes the society in general and entrepreneurs who employ the graduated students.

\section{Explanation on Components of the Developed Conceptual Framework:}

\section{The Suppliers Component}

The suppliers mean the organizations that supply raw materials to the manufacturer. Raw materials in this case are students who graduated from high schools or two-year colleges, or students who receive special quotas for admission. They can apply for admission via the computer system that can process and store the data systematically.

\section{The Manufacturer Component}

The manufacturer means the university that produces graduated students. It performs the duty to transform raw materials, or entering students, into the finished products of qualified graduated students. The university will perform its duty of student development and evaluation based upon Thailand Qualifications Framework for Higher Education (MKA 1 - MKA 7) of each activity, namely, recruitment of instructors and admission of students, curriculum planning, curriculum development, provision of learning activities for student development, provision of fieldwork experience training, evaluation of learning outcomes, and reporting of curriculum implementation results.

\section{The Education Customers Component}

The education customers mean students who graduate from the university.

\section{The Consumers Component}

The consumers mean the end-of-process component of the conceptual framework. They include the society in general and entrepreneurs who receive and/or employ the students who graduated from the university. Finally, the end product of qualified graduated students will provide added value to the supply chain . [4,5,6,7,8,9 and 10$]$

\subsection{Findings on Evaluation of the Developed Conceptual Framework}

Results for evaluation of the developed conceptual framework by 10 experts comprising 5 experts on supply chain management, 2 experts on curriculum development, and 3 experts on information technology are shown in Tables $5-9$ below: 
International Journal of Managing Value and Supply Chains (IJMVSC) Vol. 5, No. 4, December 2014

Table 5: Appropriateness of Main Components of the Conceptual Framework

\begin{tabular}{|c|l|c|c|c|}
\hline No. & \multicolumn{1}{|c|}{ Main Components } & $\bar{X}$ & S.D. & $\begin{array}{c}\text { Appropriate } \\
\text { Level }\end{array}$ \\
\hline 1 & Suppliers & 4.30 & 0.67 & High \\
\hline 2 & University (Manufacturer) & 4.00 & 1.24 & High \\
\hline 3 & Education Customers & 4.00 & 1.24 & High \\
\hline 4 & Consumers Total & 4.00 & 1.24 & High \\
\hline & \multicolumn{2}{|c|}{ Then } & 1.10 & High \\
\hline
\end{tabular}

From Table 5, it can be seen that the overall rating mean for all of the main components of the conceptual framework is at the highly appropriate level $(\bar{X}=4.07$, S.D. $=1.10)$. When the appropriateness of specific main components is considered, all four main components receive rating means at the highly appropriate level, namely, the suppliers component is rated to be appropriate at the high level $(\bar{X}=4.30$, S.D. $=0.67)$, the university (manufacturer) component, the education customer component, and the consumers component receive equal rating mean of 4.00 which is also at the highly appropriate level $(\bar{X}=4.00$, S.D. $=1.24)$.

Table 6: Appropriateness of Sub-components of the Suppliers Component

\begin{tabular}{|c|l|c|c|c|}
\hline No. & \multicolumn{1}{|c|}{ Sub-components of the Suppliers Component } & $\bar{X}$ & S.D. & $\begin{array}{c}\text { Appropriate } \\
\text { Level }\end{array}$ \\
\hline 1 & School & 4.50 & 0.52 & High \\
\hline 2 & College & 3.90 & 1.10 & High \\
\hline 3 & Family & 4.40 & 0.69 & High \\
\hline 4 & State and Private Organizations & 3.80 & 1.13 & High \\
\hline & Total & 4.15 & 0.86 & High \\
\hline
\end{tabular}

From Table 6, it can be seen that the overall rating mean for all sub-components of the suppliers component is at the highly appropriate level $(\bar{X}=4.15$, S.D. $=0.86)$. When the appropriateness of specific sub-component is considered, all four sub-components of the suppliers component receive rating means at the highly appropriate level, namely, the school sub-component is rated to be appropriate at the high level $(\bar{X}=4.50$, S.D. $=0.52)$, the family sub-component is rated to be appropriate at the high level $(\bar{X}=4.40$, S.D. $=0.69)$, the college sub-component is rated to be appropriate at the high level $(\bar{X}=3.90$, S.D. $=1.10)$, and the state and private organizations subcomponent is rated to be appropriate at the high level $(\overline{\mathrm{X}}=3.80$, S.D. $=1.13)$.

Table 7: Appropriateness of the Sub-component of the University (Manufacturer) Component

\begin{tabular}{|c|c|c|c|c|}
\hline No. & Sub-component (Operation) of the University Component & $\overline{\mathrm{X}}$ & S.D. & $\begin{array}{c}\text { Appropriate } \\
\text { Level }\end{array}$ \\
\hline 1 & Curriculum Implementation and Evaluation Process & 4.20 & 1.22 & High \\
\hline & Total & 4.20 & 1.22 & High \\
\hline
\end{tabular}


International Journal of Managing Value and Supply Chains (IJMVSC) Vol. 5, No. 4, December 2014

From Table 7, it can be seen that the sub-component in terms of curriculum implementation and evaluation process of the university (manufacturer) component is rated to be appropriate at the high level $(\bar{X}=4.20$, S.D. $=1.22)$.

Table 8: Appropriateness of the Sub-component of the Education Customer Component

\begin{tabular}{|c|c|c|c|c|}
\hline No. & $\begin{array}{c}\text { Sub-component of the Education } \\
\text { Customer Component }\end{array}$ & $\bar{X}$ & S.D. & $\begin{array}{c}\text { Appropriate } \\
\text { Level }\end{array}$ \\
\hline 1 & Graduated Students & 4.10 & 1.19 & High \\
\hline & Total & 4.10 & 1.19 & High \\
\hline
\end{tabular}

From Table 8, it can be seen that the sub-component in terms of graduate students of the education customer component is rated to be appropriate at the high level $(\bar{X}=4.10$, S.D. $=1.19)$.

Table 9: Appropriateness of the Sub-component of the Consumers Component

\begin{tabular}{|c|c|c|c|c|}
\hline No. & Sub-component of the Consumers Component & $\bar{X}$ & S.D. & $\begin{array}{c}\text { Appropriate } \\
\text { Level }\end{array}$ \\
\hline 1 & Entrepreneurs & 4.20 & 0.63 & High \\
\hline & & 4.20 & 0.63 & High \\
\hline
\end{tabular}

From Table 9, it can be seen that the sub-component in terms of entrepreneurs of the consumers component is rated to be appropriate at the high level $(\bar{X}=4.20$, S.D. $=0.63)$.

\section{CONCLUSION AND DISCUSSION}

\subsection{Conclusion}

The overall evaluation result for the synthesized conceptual framework of SCM-IS for curriculum management based on Thailand Qualifications Framework for Higher Education, as shown table 10 below:

Table 10: Appropriate Level of the Developed Conceptual Framework of SCM-IS for Curriculum Management

\begin{tabular}{|c|l|c|c|c|}
\hline No. & \multicolumn{1}{|c|}{ List of Evaluated Items } & $\bar{X}$ & S.D. & $\begin{array}{c}\text { Appropriate } \\
\text { Level }\end{array}$ \\
\hline 1 & Appropriateness of the main components & 4.07 & 1.10 & High \\
\hline 2 & $\begin{array}{l}\text { Appropriateness of sub-components of the suppliers } \\
\text { component }\end{array}$ & 4.15 & 0.86 & High \\
\hline 3 & $\begin{array}{l}\text { Appropriateness of the sub-component (operation) of } \\
\text { the university (manufacturer) component }\end{array}$ & 4.20 & 1.22 & High \\
\hline 4 & $\begin{array}{l}\text { Appropriateness of the sub-component of the } \\
\text { education customers component }\end{array}$ & 4.10 & 1.19 & High \\
\hline 5 & $\begin{array}{l}\text { Appropriateness of the sub-component of the } \\
\text { consumers component }\end{array}$ & 4.20 & 0.63 & High \\
\hline & \multicolumn{1}{|c}{ Total } & 4.14 & 1.00 & High \\
\hline
\end{tabular}


From Table 10, it can be concluded that the developed conceptual framework of SCM-IS for curriculum management based on Thailand Qualifications Framework for Higher Education is highly appropriate, with the total rating mean of 4.14. Also, its main components, subcomponents of the suppliers component, sub-component of the university component, subcomponents of the education customers component, and sub-components of the consumers component are highly appropriate, with rating means of 4.07, 4.15, 4.20, 4.10, and 4.20 respectively.

\subsection{Discussion}

Based on the above research findings, the researcher presents the following points of discussion:

1. The finding that the developed conceptual framework of SCM-IS for curriculum development based on Thailand Qualifications Framework for Higher Education is considered to be highly appropriate by the experts is probably due to the fact that this conceptual framework was carefully developed based on results of literature reviews and it received final improvement in accordance with suggestions from the experts.

2. The finding that all components of the developed conceptual framework are considered to be highly appropriate is probably due to the fact that all components are included in accordance with the supply chain management concept, starting with the suppliers and moving toward the consumers of the developed products at the end of the process.

3. The finding that the sub-components of the suppliers component are considered highly appropriate is probably due to the fact that the suppliers include all stakeholders: the school, college, family, and state and private organizations.

4. The finding that the sub-component of the university component is considered highly appropriate is probably due to the fact that the sub-component being that of the curriculum implementation and evaluation process which is the focal process for student development that includes all instructional and co-curricular activities.

5. The finding that the sub-component of the education customers component is considered highly appropriate is probably due to the fact that the students constitute the subcomponent of the education customers component, and the framework focuses on desirable qualities of the graduated students.

6. The finding that the sub-components of the consumers component are considered highly appropriate is probably due to the fact the consumers component includes the society in general and entrepreneurs that receive and/or employ the graduated students who are the end-product of development.

\section{RECOMMENDATIONS}

1. Although the developed conceptual framework is considered highly appropriated, it has not been actually implemented in any university. Therefore, if possible it should be implemented in some university. The feedback information from the implementation could be used to further revise or improve the conceptual framework.

2. Further in-depth studies should be conducted on the creation of required database for the developed conceptual framework. 
3. There should be case studies of higher education institutions that develop or implement the conceptual framework effectively and efficiently, if any.

\section{ACKNOWLEDGEMENTS}

The researcher would like to thank Assistant Professor Dr. Pallop Piriyasurawong, other dissertation committee members, 5 experts on supply chain management, 3 experts on information technology, and 2 experts on curriculum development from within and outside the institution, who kindly provided supervision and advices, and served as good models for the researcher in conducting this study.

\section{REFERENCES}

[1]Office of the National Economic and Social Development Board, (2012) , "The Eleventh National Economic and Social Development Plan (B.E. 2011 - 2016) ". Available : http://www. nesdb.go.th. /Portals/0/news/plan/p11/plan11.pdf. [Aug. 11, 2014].

[2] _, (2006) , "The Eleventh National Economic and Social Development Plan (B.E. 2007 - 2012) " Available : http://www. nesdb. go.th/?tabid=139. [Aug. 11, 2014].

[3] Noimo, C. ,(2007). "Problem Conditions for Development of Preschool Children Development Centers in Huay Phueng District, Kalasin Province" ( an M.A. independent study). Khon Kaen University, Bangkok.

[4] Office of the Commission on Higher Education., (2009), "National Qualifications Framework for Higher Education". Available : http://www. mua.go.th /users/tqf-hed, . [Aug. 11, 2014].

[5]Habib, M, (2010), “An empirical Research of ITESECM: integrated tertiary educational supply chain management model”. Available : http://www. academia. edu/MamunHabib. [Aug 11, 2014].

[6] _ (2012), "An Empirical Study of Tertiary Educational Supply Chain Management”. Available : http://www. academia. edu/MamunHabib. [Aug. 11, 2014].

[7] __ , (2012), "An Empirical Research of Educational Supply Chain for the Universities". Available : http://www.academia. edu/MamunHabib. [Aug. 11, 2014].

[8] Habib, M., and C. Jungthirapanich, (2009), "Research Framework of Education Supply Chain, Research Supply Chain and Educational Management for the Universities". Available: http://www. academiaedu/MamunHabib. [Aug. 11, 2014].

[9] _ (2010), “An Empirical Study of Educational Supply Chain Management for the Universities”. Available: http://www.iieom.org/paper/185\%20Mamun\%20Habib.pdf. [Aug. 11, 2014].

[10] (2008), “An Integrated Framework for Research and Education Supply Chain for the Universities”. Available: http://www. academia. edu/MamunHabib. [Aug, 11, 2014].

\section{Authors}

Mr. Artaphon Chansamut is $\mathrm{PhD}$. Student Division of Information and Communication Technology for Education, Faculty of Technical Education, King Mongkut's University of Technology N orth Bangkok .

Pallop Piriyasurawong is Assistant Professor of Division of Information and Communication Technology for Education, Faculty of Technical Education, King Mongkut's University of Technology North Bangkok. His area of current interest includes ICT for Education, Innovation for Education, etc.
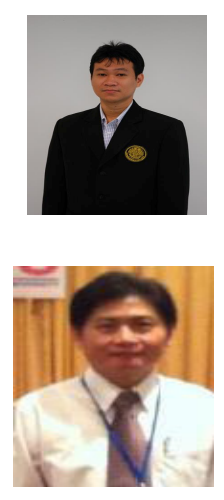